\title{
Alkali-Aggregate Reaction: A study of the influence of the petrographic characteristics of volcanic rocks
}

\author{
Francieli Tiecher \\ Polytechnic School of Civil Engineering \\ IMED Passo Fundo \\ Brazil \\ francieli.bonsembiante@imed.edu.br
}

\author{
Marcia E. B. Gomes \\ Department of Geology \\ Universidade Federal do \\ Rio Grande do Sul \\ Porto Alegre, Brazil \\ marcia.boscato@ufrgs.br
}

\author{
Denise C. C. Dal Molin \\ Department of Civil Engineering \\ Universidade Federal do Rio \\ Grande do Sul \\ Porto Alegre, Brazil \\ dmolin@ufrgs.br
}

\begin{abstract}
When the rock involved in the alkali-aggregate reaction (AAR) is volcanic, the matter present in the interstices of the grains, called mesostasis is considered responsible for the expansions. Mesostasis is a residue which consists of mineral phases rich in silica and alkalis ( $\mathrm{K}$ and $\mathrm{Na}$ ) and in optical microscopy looks like amorphous matter. By means of scanning electron microscopy (SEM) and with the aid of energy dispersive spectroscopy (EDS), the presence of well-crystallized mineral phases in mesostasis can be observed. The objective of this study was to evaluate the amount, the chemical composition and the degree of crystallinity of mesostasis on the reactive potentiality of volcanic rocks.
\end{abstract}

Keywords: alkali-aggregate reaction; volcanic rocks; basalt; rhyolite

\section{INTRODUCTION}

Mesostasis originates from the abrupt cooling of magma when volcanic rocks form. It consists of micro-tocryptocrystalline phases, which in optical microscopy look like amorphous matter and is often confused with volcanic glass. In an alkali-aggragate reaction with basic rocks being used, alkalireactive phases appear to be in mesostasis state. If acid rocks are used quartz is mainly responsible for the reaction. Alkaliaggregate reaction develops when the silica present in aggregates reacts with the alkali hydroxides coming from cement. Using scanning electron microscopy, with the aid of EDS, the presence of small crystals of K-feldspar and quartz can be identified in this interstitial material [1]. There seems to be no direct relationship between the amount of microcrystalline, or amorphous matter present in the rocks and the expansions resulting from the alkali-aggregate reaction (AAR) [2]. A rock with hardly any mesostasis can represent expansions similar to other rock with a lot of mesotasis [3-5]. Quantifying the silica present in the mesostasis can explain this behavior. The objective of this work was to analyze the characteristics of the interstitial matter present in the mesostasis and to correlate with the expansions triggered by the AAR.

\section{EXPERIMENTAL PROGRAM}

\section{A. Methods}

Characterizing and quantifying the mineral phases in the rocks studied, as well as characterizing the mesostasis, were conducted by petrographic analysis, along with modal analysis (point counting by area). X-ray diffraction (XRD) assisted in the mineralogical characterization of the samples, but mainly in identifying clay minerals by the non-oriented powder method [6]. For the chemical analysis of the samples, X-ray fluorescence (XRF) was employed. Scanning electron microscopy (SEM), along with energy dispersion spectroscopy (EDS), was used to analyze in greater depth the different features of mesostasis previously identified in petrographic analysis. For this analysis, the same $30 \mu \mathrm{m}$-thick slides as in the petrographic analysis were used, and metalized with carbon. In order to quantify the alkali-reactive potential of each sample, the accelerated mortar bar test $[7,8]$ was used.

\section{B. Materials}

Two types of volcanic rocks were used in this study: a basalt (basic rock) and a rhyolite (acid rock). By using petrographic analysis, it was verified that the basalt has a fine granulation, consisting of plagioclase (44.1\%), pyroxene (28.5\%), opaque minerals ( $\mathrm{Fe}$ and $\mathrm{Ti}$ oxides, $7.7 \%$ ), clay minerals $(5.8 \%)$ and mesostasis $(13.8 \%)$. It was also possible to observe phenocrystals of plagioclase, pyroxene, Fe and $\mathrm{Ti}$ oxides and some traces of apatite and hematite. The XRD of this rock ratifies the mineralogy observed in the petrographic analysis and reveals the presence of quartz, indicating that there are grains that could not be identified with optical microscopy. In basalt, quartz is found in the interstitial mesostasis [9]. Figure 1 shows the diffractogram of a fraction smaller than 2 $\mu \mathrm{m}$ in the oriented sample, thereby giving evidence of the clay minerals. The XRD of the sample in the natural form shows the presence of a peak around $15 \AA$, which moves to the left (position $16.5 \AA$ ) in the glycolated condition and disappears after calcination, a characteristic behavior of expansive, smectite clay minerals $[10,11]$. These clay minerals can contribute to AAR occurring in concrete, both because of the expansibility and the possibility of reaction with the alkali hydroxides. The XRF analysis (Table I) shows that the basalt has a high amount of silica: $54.04 \%$, which is common to tholeitic basalts [12]. This percentage corresponds mainly to the silica needed to form the main minerals of the rock, which are the plagioclases and pyroxenes. The 'free silica' (quartz), which is more prone to react, corresponds to a smaller percentage present in the mesostasis [13]. By using the petrographic analysis, with the help of the XRD, it was verified that the rhyolite consists of K-feldspar (1.2\%), quartz (5.8\%), 
plagioclase $(8.9 \%)$, pyroxene $(7.8 \%)$, Ti-magnetite $(9.4 \%)$, and mesostasis $(15.2 \%)$, and contains traces of apatite, hematite and clay minerals (smectite - Figure 2). Its granulation is fine and the intergranular mesostasis can be microcrystalline or filled with automorphic crystals of quartz and $\mathrm{K}$-feldspars, this being more abundant in the vesicular levels. The XRF showed that rhyolite consists of $67.98 \%$ of silica. This silica represents the quartz of the matrix of the rock and also the grains in the microcrystalline form in the mesostasis. The percentage of $\mathrm{K}_{2} \mathrm{O}$ and $\mathrm{Na}_{2} \mathrm{O}$ in the rhyolite sample is higher than in basalt, emphasis being given to $\mathrm{K}_{2} \mathrm{O}$, due to the more expressive presence of K-feldspar in this rock. The presence of these constituents may increase the alkali hydroxides in the pores of the concrete if there is dissolution. Thus, the rhyolitic sample could contribute both to the dissolution of silica and to the dissolution of alkalis.

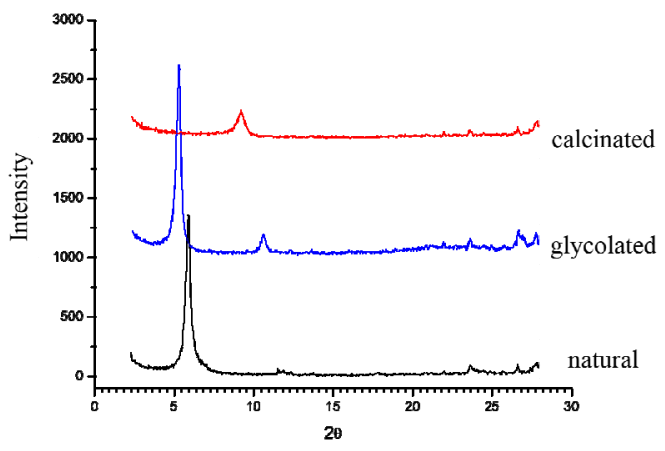

Fig. 1. Diffractogram of the clay minerals present in basalt

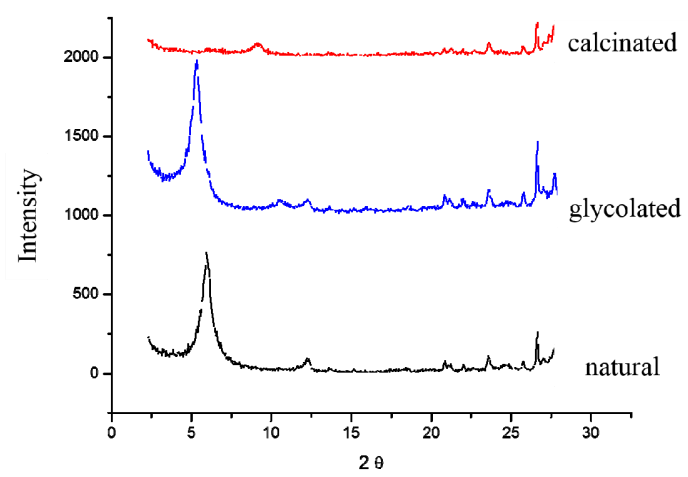

Fig. 2. Diffractogram of clay minerals present in rhyolite

TABLE I. CHEMICAL COMPOSITION OF THE ROCKS

\begin{tabular}{|c|c|c|}
\hline \multirow{2}{*}{ Compound } & \multicolumn{2}{|c|}{ Results } \\
\cline { 2 - 3 } & Basalt & Rhyolite \\
\hline $\mathrm{SiO}_{2}$ & 54.04 & 67.98 \\
\hline $\mathrm{Al}_{2} \mathrm{O}_{3}$ & 16.71 & 11.75 \\
\hline $\mathrm{TiO}_{2}$ & 0.94 & 1.15 \\
\hline $\mathrm{Fe}_{2} \mathrm{O}_{3}$ (total) & 10.33 & 7.32 \\
\hline $\mathrm{MnO}$ & 0.18 & 0.12 \\
\hline $\mathrm{MgO}$ & 4.81 & 0.74 \\
\hline $\mathrm{CaO}$ & 9.22 & 2.38 \\
\hline $\mathrm{Na} \mathrm{O}_{2} \mathrm{O}$ & 1.73 & 1.89 \\
\hline $\mathrm{K}_{2} \mathrm{O}$ & 1.39 & 4.15 \\
\hline $\mathrm{P}_{2} \mathrm{O}_{5}$ & 0.14 & 0.18 \\
\hline Loss to fire & 0.70 & 1.01 \\
\hline $\mathrm{TOTAL}$ & 100.21 & 98.68 \\
\hline \multicolumn{2}{|c}{} &
\end{tabular}

\section{RESULTS AND DISCUSSION}

\section{A. Interstitial Matter Analysis}

The reactivity of the volcanic rocks comes from the interstitial material of low crystallinity: volcanic glass and/or mesostasis [14-16]. After characterizing the rocks selected for the study (item II), the mesostasis analysis was conducted. The first finding, obtained by the petrographic analysis, was the presence of different types of mesostasis in the same rock: microcrystalline mesostasis; mesostasis with better crystalized grains; mesostasis with predominance of clay minerals. The name microcrystalline mesostasis was given to the matter of low crystallinity, rich in silica and alkalis, and accompanied by small grains of hematite and needles of apatite, since optical microscopy cannot individualize grains of quartz or feldspar. The mesostasis with better crystalized grains is the one where there is dissemination of quartz grains that can be visualized in optical microscopy, associated to the matter that consists of feldspar, clay minerals and apatites. The mesostasis with predominance of clay minerals is the one formed by cryptocrystalline quartz-feldspar matter accompanied by an abundant amount of clay minerals, which form well-developed aggregates, with fibro-radiated forms, of greenish color, the smectites (XRD confirming this). Table II presents the percentages of each type of mesostasis in both rocks. The features observed, under petrographic analysis are shown in Figure 3.

TABLE II. ROCK MESOSTASIS PERCENTAGE

\begin{tabular}{|c|c|c|}
\hline \multirow{2}{*}{ Mesostasis Type } & \multicolumn{2}{|c|}{ Sample } \\
\cline { 2 - 3 } & Basalt & Rhyolite \\
\hline Mesostasis with predominance of clay minerals & 3.00 & 0.20 \\
\hline Microcrystalline mesostasis & 7.00 & 10.00 \\
\hline Mesostasis with better crystallized grains & 0.25 & 5.00 \\
\hline TOTAL & 10.25 & 15.20 \\
\hline
\end{tabular}

On comparing the texture of the samples (Figure 4), it can be seen that regions of the rhyolite have higher mesostasis concentrations, very often distributed radially. In the basalt, the mesostasis are completely disseminated among the grains. The chemical and mineralogical composition of the different mesostasis identified is also distinct, and may directly influence the potential of the expansion due to the AAR. Then, using optical microscopy, regions were selected for analysis by using SEM and EDS. Figure 5 shows a basalt region containing mesostasis with clay minerals. This image, obtained by SEM, of the relief of the region containing clay materials shows that they are different from the other minerals present (Figure 5(c)). While the plagioclases and pyroxenes present a flat aspect, the clay minerals show scaling. This aspect is due to their lamellar shape and their very small size, which makes it difficult to polish the lamina used for the analysis. The clay minerals contribute to the AAR due to silica and alkalis easily dissolving $[17,18]$. The EDS analysis presented in Figure 5(d) confirms the presence of these clay minerals in the mesostasis, since the main constituents of the clays are $\mathrm{Na}, \mathrm{K}, \mathrm{Ca}, \mathrm{Al}, \mathrm{Mg}, \mathrm{Si}$ [19].

In order to explore the specific region of the mesostais in greater detail and to verify the possible presence of quartz micrograins in this region, a chemical elements mapping which could characterize clay minerals and quartz was carried out. In 
this case, the mapped elements were $\mathrm{Si}, \mathrm{Ca}, \mathrm{K}, \mathrm{Fe}$ (Figure 6, which is an enlarged mesostasis region shown in Figure 5). The analysis showed that there are regions in the mesostasis with clay minerals that are rich in $\mathrm{Si}$ (Figure 6(b)). In these regions, the amount of $\mathrm{K}, \mathrm{Ca}$ and $\mathrm{Fe}$ is lower (Figure 6(c), 6(d) and 6(e)). On comparing the $\mathrm{Si}$ and $\mathrm{K}$ maps, it is observed that when there is a higher concentration of $\mathrm{Si}$, the concentration of $\mathrm{K}$ decreases, that is, even when it contains predominantly clay minerals, microcrystalline quartz occurs.

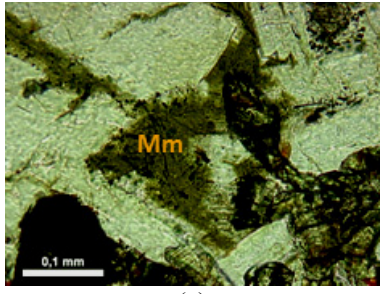

(a)

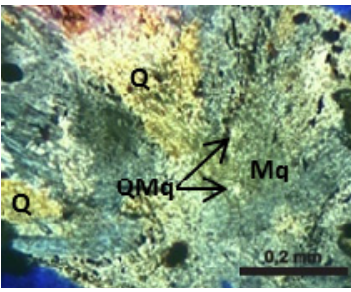

(b)

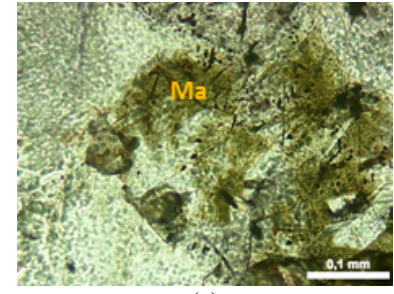

(c)

Fig. 3. Micrographs of the mesostasis of the basalt and rhyolite samples, where $\mathrm{Mm}=$ microcrystalline mesostasis, Mq=best crystallized mesostasis, $\mathrm{Q}=\mathrm{matrix}$ quartz, QMq=quartz of the mesostasis, Ma=mesostasis with clay minerals. (a) Mm, natural light, (b) Mq, cross polarized, (c) Ma, natural light. Magnification 20x.

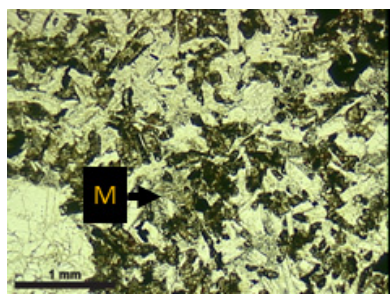

(a)

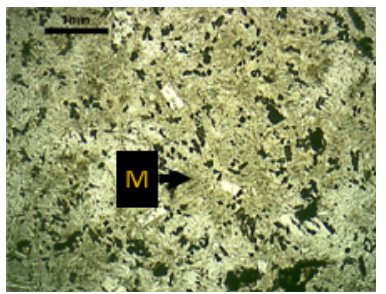

(b)

Fig. 4. Texture of the samples, where $\mathrm{M}=$ mesastasis. (a) basalt, (b) rhyolite. $2.5 \mathrm{x}$ magnification, natural light.

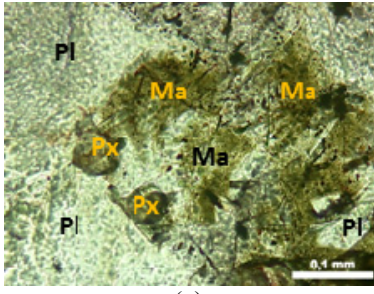

(a)

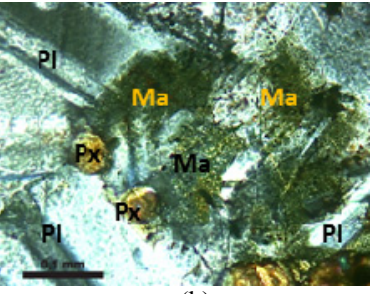

(b)

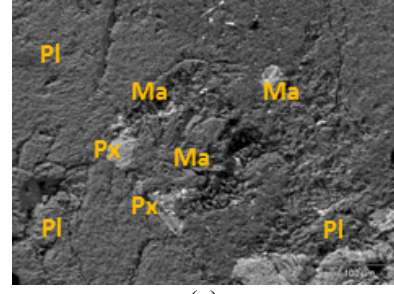

(c)

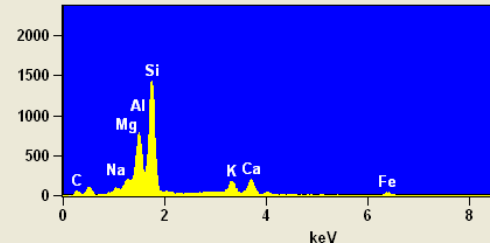

(d)

Fig. 5. Mesostasis with clay minerals of the basalt, where $\mathrm{Pl}=$ plagioclase, $\mathrm{Px}=$ pyroxene, Ma=mesostasis with clay minerals. (a) and (b) micrographs obtained by light microscopy under natural light and crossed polarizer, magnification 20x, (c) micrograph obtained by SEM, 250x, (d) analysis by using EDS.

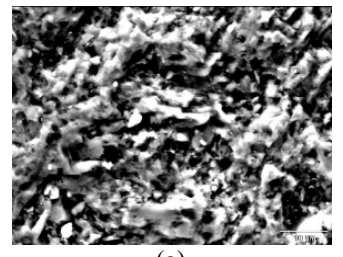

(a)

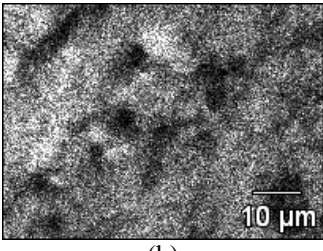

(b)

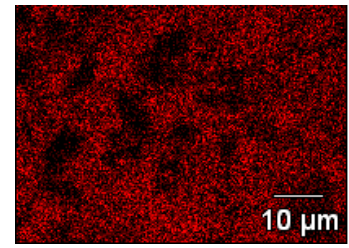

(c)

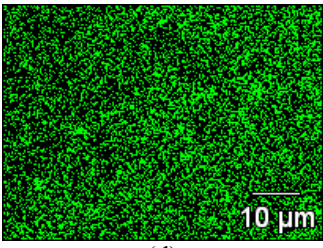

(d)

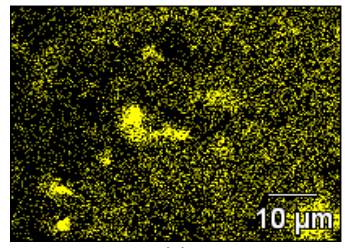

(e)

Fig. 6. Mapping of the chemical elements in a region containing mesostasis with clay minerals of basalt. (a) micrograph of the region of analysis, 2000x magnification, (b) concentration of $\mathrm{Si}$, (c) concentration of $\mathrm{K}$, (d) concentration of $\mathrm{Ca}$, (e) concentration of Fe.

Figure 7 shows, in the images obtained from SEM, that the texture of the microcrystalline mesostasis is very homogeneous, unlike what was observed in the mesostasis with clay minerals. The differentiation between the mesostasis and the other minerals was made because of the difference of tonality, since the microcrystalline mesostasis forms a darker region (Figure 7(c)). On using EDS analysis (Figure 7(d)), only $\mathrm{Si}$ was identified in the region where the microcrystalline mesostasis is located. This findings show that the mesostasis characterized as microcrystalline basically consists of microcrystalline quartz, unlike what was identified in the mesostasis with clay minerals. The analysis conducted by mapping the chemical elements corroborates this statement, since there is a great concentration of Si (Figure 9(b)). Another observation is the absence of clay minerals, evidenced by the low concentration of Ca (Figure 9(d)) [17]. The elements K, $\mathrm{Ca}$, and $\mathrm{Fe}$ are found only in well crystallized minerals, in the plagioclase $(\mathrm{K}, \mathrm{Ca})$ and in pyroxene $(\mathrm{Ca}, \mathrm{Fe})[20,21]$. The quartz present in the microcrystalline mesostasis is smaller than $1 \mu \mathrm{m}$, as shown in the analysis presented in Figure 8. 


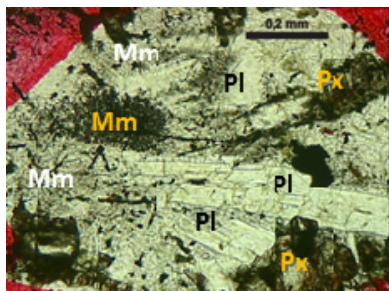

(a)

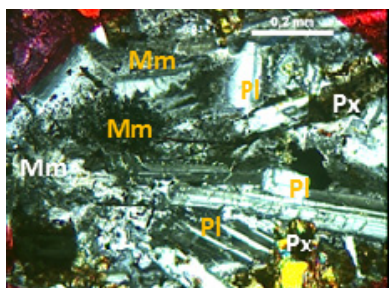

(b)

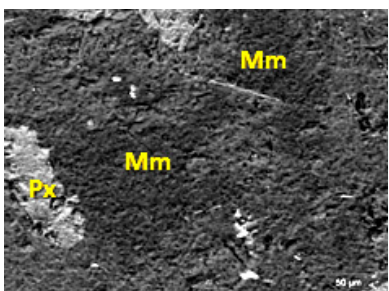

(c)

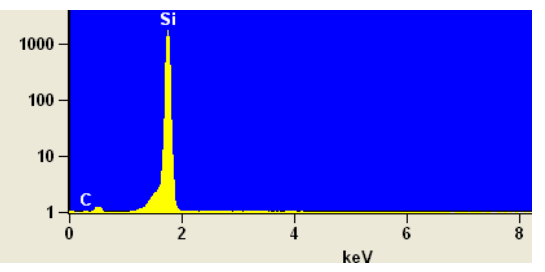

(d)

Fig. 7. Microcrystalline mesostasis of the basalt, where $\mathrm{Pl}=$ plagioclase, $\mathrm{Px}=$ pyroxene, $\mathrm{Mm}=$ microcrystalline mesostasis. (a) and (b) micrographs obtained by light microscopy under natural light and crossed polarizer, magnification 20x, (c) micrograph obtained by SEM, 250x, (d) analysis by using EDS.

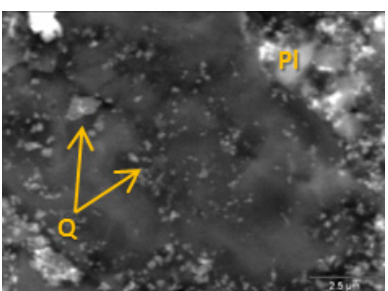

(a)

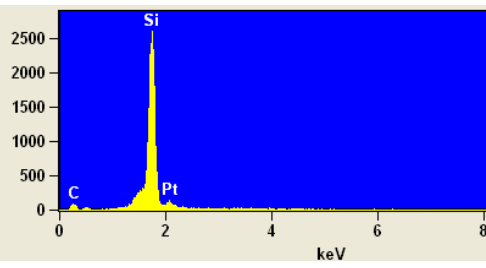

(b)

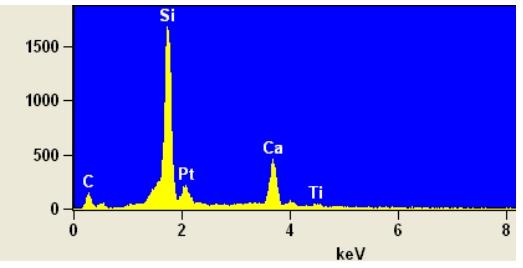

(c)

Fig. 8. Analysis by SEM and EDS in the region containing the microcrystalline mesostasis in basalt, where $\mathrm{Q}=\mathrm{Quartz}, \mathrm{Pl}=\mathrm{plagioclase}$. (a) micrograph of the region of analysis, magnification 5000x, (b) quartz, (c) plagioclase.

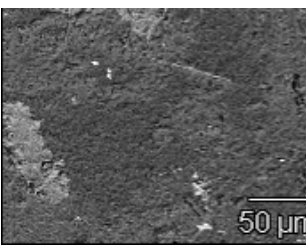

(a)

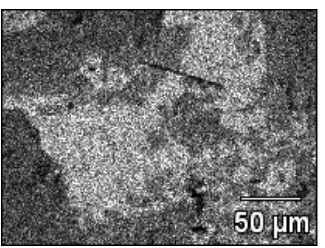

(b)

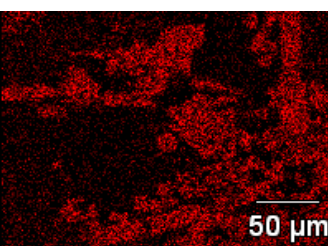

(c)

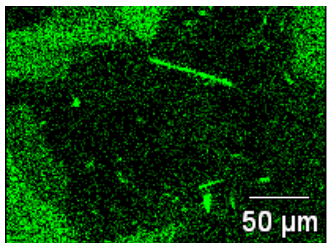

(d)

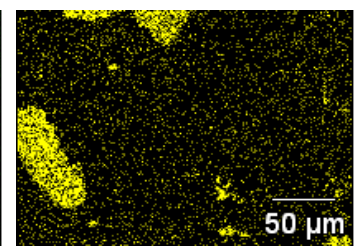

(e)

Fig. 9. Mapping of the chemical elements in the region containing microcrystalline mesostasis of basalt. (a) micrograph of the region of analysis, magnification 500x, (b) concentration of $\mathrm{Si}$, (c) concentration of $\mathrm{K}$, (d) concentration of $\mathrm{Ca}$, (e) concentration of $\mathrm{Fe}$.

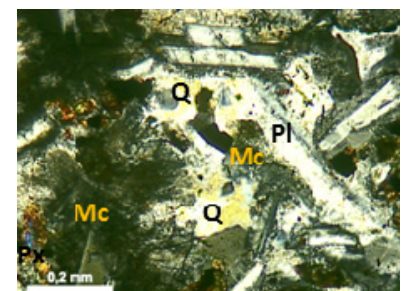

(a)

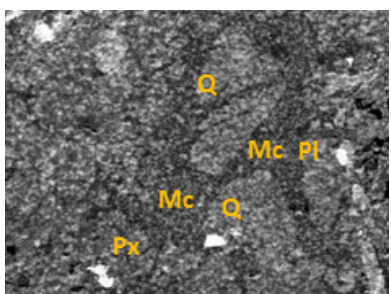

(b)

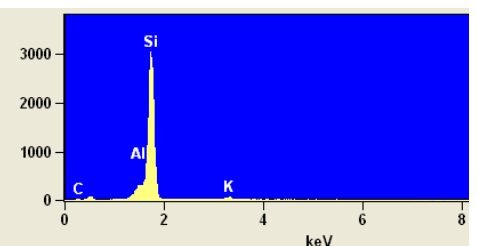

(c)

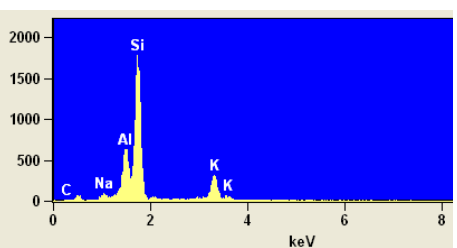

(d)

Fig. 10. Region containing mesostasis of greatest crystallinity, where $\mathrm{Q}=$ quartz, $\mathrm{Mc}=$ best crystallized mesostasis, $\mathrm{Pl}=\mathrm{plagioclase}, \mathrm{Px}=\mathrm{pyroxene}$. (a) micrograph obtained by optical microscopy under cross polarizer, 10x magnification, (b) micrograph obtained using SEM, 150x, (c) quartz of the mesastasis, (d) plagioclase.

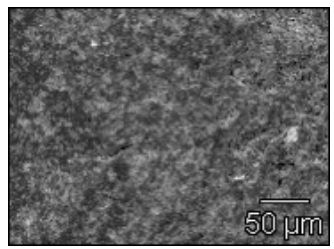

(a)

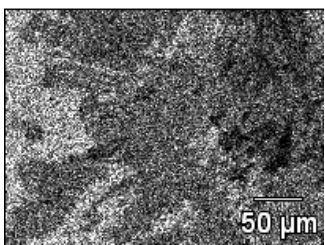

(b)

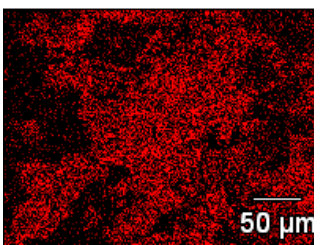

(c)

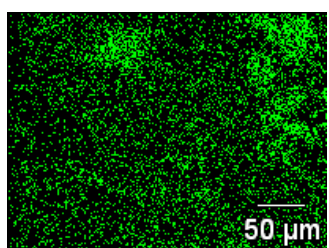

(d)

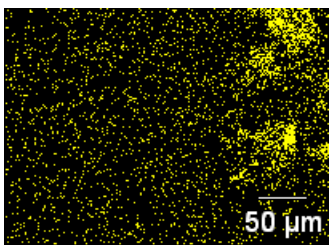

(e)

Fig. 11. Mapping of the chemical elements in a region with mesostasis containing quartz grains in the rhyolite. (a) micrograph of the region of analysis, magnification $500 \mathrm{x}$, (b) concentration of $\mathrm{Si}$, (c) concentration of $\mathrm{K}$, (d) concentration of $\mathrm{Ca}$, (e) concentration of $\mathrm{Fe}$.

Figure 10 shows that the texture of mesostasis of greatest crystallinity, in SEM is homogeneous, similar to that observed in the microcrystalline mesostasis (Figure 10(b)). However, small grains of quartz were observed in the mesostasis (Figure 10(a)), which was confirmed by EDS (Figure 10(c)). The mapping of the chemical elements was carried out in a region of the best crystallized mesostasis. As in the other mappings presented, the identification of the presence of Si coincided with the absence of other elements $(\mathrm{K}, \mathrm{Ca}$ and $\mathrm{Fe})$, indicating that this region consists of micrograins of quartz. 


\section{B. Analysis of the Potential of Development of AAR}

Figure 12 shows the expansions over time in the accelerated mortar bar test $[6,7]$. It is observed that both are potentially reactive, in accordance with the classification of ASTM C 1260 , which establishes that an aggregate is potentially reactive when the expansions are superior to $0.10 \%$ at 30 days. The basalt resulted in $26 \%$ higher expansions at the end of the test, even though it had a smaller amount of mesostasis than rhyolite. An important distinction between the mesostasis is their distribution on the rocks. While in basalt, they are disseminated among the grains, in rhyolite it is common to find regions with larger concentrations, where it is distributed radially. This may be an indication that the dissemination of the mesostasis among the minerals (as for basalt) increases its reaction potential with alkaline hydroxides due to the more uniform availability of material and ease of dissolution. There is also a great difference between the quantities of mesostasis with clay minerals of the rocks, where rhyolite has a very small amount. When there is a predominance of clay minerals, the amount of free silica (quartz) available to react is lower. However, the ease of making both silica and alkalis (constituents of clay minerals) soluble makes them important for enhancing AAR. Apparently the best crystallized mesostasis does not interfere with the intensity of the reaction. The fact of the grains being better crystallized hinders the attack of alkaline hydroxides.

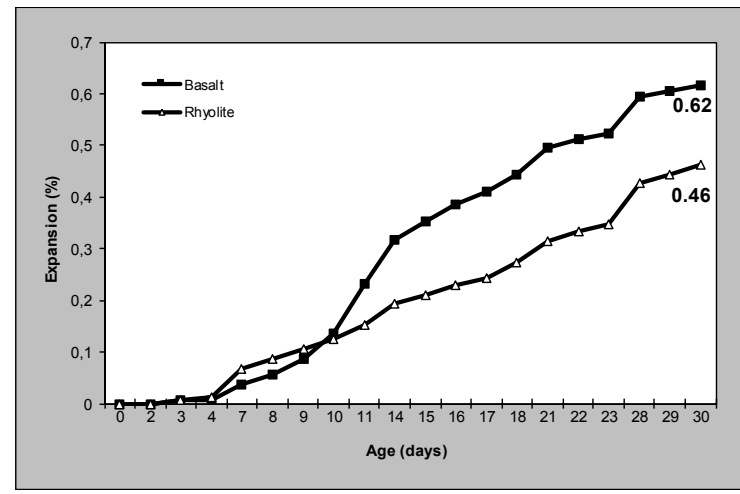

Fig. 12. Accelerated mortar bar test

\section{CONCLUSIONS}

At the end of the research it was verified that the interstitial matter present in the volcanic rocks can be very heterogeneous. In the rocks selected, three types of mesostasis were differentiated, namely: microcrystalline mesostasis which is rich in microcrystalline quartz grains, identifiable only by using SEM and EDS, mesostasis with predominance of clay minerals, and the best crystallized mesostasis, where the quartz present in the interstitial material can be identified by optical microscopy. According to the results of the expansion assay, the presence of microcrystalline mesostasis between the grains of the rock, as well as mesostasis with clay minerals increases its potential for expansion due to the AAR. It was also verified that the amount of mesostasis is not a preponderant factor for the intensity of expansion resulting from the reaction. According to the obtained results, the constitution of the mesostasis and its distribution in the rock are the main characteristics that potentiate the reactivity of a volcanic rock. However, a larger number of samples needs to be analyzed in order to confirm these conclusions.

\section{ACKNOWLEDGMENTS}

The authors would like to thank IMED for supporting the research, UFRGS for making materials, equipment and laboratories available and the National Council for Research (CNPQ) for the financial support.

\section{REFERENCES}

[1] M. E. B. Gomes, Mecanismes de refroidissement, structurat et processus post-magmatiques des basaltes du bassin du Parana - region de Frederico Westphalen (RS) - Bresil, PhD Thesis, Universidade Federal do Rio Grande do Sul, 1996

[2] F. Tiecher, Reacao alcali-agregado: avaliacao do comportamento de agregados do sul do Brasil quando se altera o cimento utilizado, MSc. Report, Universidade Federal do Rio Grande do Sul, 2006

[3] L. Valduga, Influence of ASTM C 1260 test conditions to verify alkaliaggregate reaction, PhD Thesis, Universidade Federal do Rio Grande do Sul, 2007

[4] L. Valduga, D. C. C. Dal Molin, V. A. Paulon, "Basalts potential reactivity survey in Brazil", 2th Simposio Sobre Reacao AlcaliAgregado Em Estruturas De Concreto, 2006

[5] A. A. Silveira, Contribution to the Study of Rice Husk Ash Admixtures on Concretes Submitted to Alkali-Agreggate Reactions, PhD Thesis, UFRGS, 2007

[6] D. B. Alves, "Desenvolvimento da metodologia de preparacao de amostras para analise difratometrica de argilominerais no centro de pesquisas da Petrobras", Boletim de Geociencias da Petrobras, Rio de Janeiro: Petrobras, Vol. 1, No. 2, pp. 157-175, 1987

[7] Associacao Brasileira de Normas Tecnicas, NBR 15577-4: Agregados Reatividade alcali-agregado - Parte 4: Determinacao da expansao em barras de argamassa pelo metodo acelerado, 2008

[8] Annual Booking of American Society for Testing and Materials, ASTM C 1260-01: Standard test method for potential alkali reactivity of aggregates (mortar-bar method), Annual Book of ASTM Standards, 2001

[9] Y. Wakizaka, "Alkali-silica reactivity of Japanese rocks", Developments in Geotechnical Engineering, Vol. 84, pp. 293-303, 2000

[10] J. T. Kloprogge, S. Komarneni, J. E. Amonette, "Synthesis of smectite clay minerals: a critical review", Clays and Clay Minerals, Vol. 47, No. 5, pp. 529-554, 1999

[11] A. R. V. Silva, H. C. Ferreira, "Esmectitas organofilicas: conceitos, estruturas, propriedades, sintese, usos industriais e produtores/fornecedores nacionais e internacionais", Revista Eletronica de Materiais e Processos, Vol. 3, No. 3, pp. 1-11, 2008

[12] L. S. Marques, M. Ernesto, "Magmatismo toleitico da bacia do Parana", Geologia do Continente Sul-Americano: evolucao da obra de Fernanado Flavio Marques de Almeida, pp. 245-263, 2004

[13] A. J. R. Nardy, F. B. Machado, M. A. F. de Oliveira, "As rochas vulcanicas mesozoicas acidas da Bacia do Parana: litoestratigrafia e consideracoes geoquimico-estatigraficas", Revista Brasileira de Geociencias, Vol. 38, No. 1, pp. 178-195, 2008

[14] M. Korkanc, A. Trugrul, "Evaluation of selected basalts form the point of alkali-silica reactivity", Cement and Concrete Research, Vol. 35, No. 3, pp. 505-512, 2005

[15] P. Krivenko, R. Drochytka, A. Gelevera, E. Kavalerova, "Mechanism of preventing the alkali-aggregate reaction in alkali-activated cement concretes", Cement and Concrete Composites, Vol. 45, pp. 157-165, 2014

[16] M. S. Islam, M. S. Alam, N. Ghafoori, R. Sadiq, "Role solution concentration, cement alkali and test duration on expansion of accelerated mortar bar test (AMBT)", Materials and Structures, Vol. 49, No. 5, pp. 1955-1965, 2015 
[17] S. Sujjavanich, T. Meesak, D. Chayasuwan, "Effect of clay brick powder on ASR expansion control of rhyolite mortar bar", Advanced Materials Research, Vol. 931-932, pp. 441-445, 2014

[18] A. Leemann, T. Katayama, I. Fernandes, M. A. R. Broekmans, "Types of alkali-aggregate reactions and products formed", Construction Materials, Vol. 169, No. 3, pp. 128-135, 2016

[19] C. Igarashi, I. Maruyama, Y. Nishioka, H. Yoshida, "Influence of mineral composition of siliceous rock on its volume change", Construction and Building Materials, Vol. 94, pp. 701-709, 2015

[20] H. Chamley, Clay Sedimentology, Springer-Verlang, 1989

[21] J. M. Ponce, O. R. Batic, "Different manifestation of the alkali-silica reaction in concrete according to the reaction kinetics of the reactive aggregate", Cement and Concrete Research, Vol. 36, No. 6, pp. 11481156,2006 